\title{
Association of genetic variations with pharmacokinetics and lipid-lowering response to atorvastatin in healthy Korean subjects
}

\author{
This article was published in the following Dove Press journal: \\ Drug Design, Development and Therapy \\ 4 April 2017 \\ Number of times this article has been viewed
}

\section{Hye In Woo' \\ Suk Ran Kim² \\ Wooseong Huh ${ }^{3,4}$ \\ Jae-Wook Ko ${ }^{4}$ \\ Soo-Youn Lee ${ }^{4,5}$}

'Department of Laboratory Medicine, Samsung Changwon Hospital, Sungkyunkwan University School of Medicine, Changwon, Korea; ${ }^{2}$ Clinical Research and Development, Hanmi Pharm. Co., Ltd., Seoul, Korea; ${ }^{3}$ Department of Medicine, ${ }^{4}$ Department of Clinical Pharmacology and Therapeutics, ${ }^{5}$ Department of Laboratory Medicine and Genetics, Samsung Medical Center, Sungkyunkwan University School of Medicine, Seoul, Korea
Correspondence: Soo-Youn Lee Department of Laboratory Medicine and Genetics, Samsung Medical Center, \#50, Irwon-dong, Gangnam-gu, Seoul, |35-7|0, Korea

$\mathrm{Tel}+82234101834$

Fax +82234102719

Email syl17.lee@samsung.com
Background: Statins are effective agents in the primary and secondary prevention of cardiovascular disease, but treatment response to statins varies among individuals. We analyzed multiple genetic polymorphisms and assessed pharmacokinetic and lipid-lowering responses after atorvastatin $80 \mathrm{mg}$ treatment in healthy Korean individuals.

Methods: Atorvastatin $80 \mathrm{mg}$ was given to 50 healthy Korean male volunteers. Blood samples were collected to measure plasma atorvastatin and lipid concentrations up to 48 hours after atorvastatin administration. Subjects were genotyped for 1,936 drug metabolism and transporter genetic polymorphisms using the Affymetrix DMET plus array.

Results: The pharmacokinetics and lipid-lowering effect of atorvastatin showed remarkable interindividual variation. Three polymorphisms in the $S L C O 1 B 1, S L C O 1 B 3$, and $A B C C 2$ genes were associated with either the maximum concentration $\left(\mathrm{C}_{\max }\right)$ of atorvastatin or changes in total cholesterol or low-density lipoprotein cholesterol (LDL-C). Minor homozygotes $(76.5 \mathrm{ng} / \mathrm{mL}$ ) of SLCO1B1 c.-910G $>$ A showed higher $\mathrm{C}_{\text {max }}$ than heterozygotes $(34.0 \mathrm{ng} / \mathrm{mL})$ and major homozygotes $(33.5 \mathrm{ng} / \mathrm{mL}$, false discovery rate $P=0.040) . \mathrm{C}_{\max }$ and the area under the plasma concentration curve from hour 0 to infinity $\left(\mathrm{AUC}_{\infty}\right.$ ) were higher in carriers of the $S L C O 1 B 1 * 17$ haplotype that included c.-910G $>$ A than in noncarriers (46.1 vs $32.8 \mathrm{ng} / \mathrm{mL}$ for $\mathrm{C}_{\max } ; 221.5 \mathrm{vs} 154.2 \mathrm{ng} / \mathrm{mL}$ for $\left.\mathrm{AUC}_{\infty}\right)$. SLCO1B3 c.334G $>$ T homozygotes $(63.0 \mathrm{ng} / \mathrm{mL})$ also showed higher $\mathrm{C}_{\max }$ than heterozygotes $(34.7 \mathrm{ng} / \mathrm{mL})$ and major homozygotes $(31.4 \mathrm{ng} / \mathrm{mL}$, FDR $P=0.037)$. A nonsynonymous $A B C C 2 \mathrm{c} .1249 \mathrm{G}>\mathrm{A}$ was associated with small total cholesterol and LDL-C responses $(0.23 \%$ and $-0.70 \%$ for $\mathrm{G} / \mathrm{A}$ vs $-11.9 \%$ and $-17.4 \%$ for $\mathrm{G} / \mathrm{G}$ ). The $\mathrm{C}_{\max }$ tended to increase according to the increase in the number of minor allele of $S L C O 1 B 1$ c.-910G $>$ A and $S L C O 1 B 3$ c.334G $>$ T.

Conclusion: Genetic polymorphisms in transporter genes, including SLCO1B1, SLCO1B3, and $A B C C 2$, may influence the pharmacokinetics and lipid-lowering response to atorvastatin administration.

Keywords: atorvastatin, pharmacokinetics, pharmacogenomics, SLCO1B1, SLCO1B3, $A B C C 2$

\section{Introduction}

As therapeutic agents administered to reduce the risk of cardiovascular disease and manage hypercholesterolemia, ${ }^{1}$ statins upregulate low-density lipoprotein (LDL) receptors, increase plasma clearance of LDL, and reduce hepatic secretion of apolipoprotein B (ApoB)-containing lipoproteins, very low-density lipoprotein (VLDL), and LDL. Statins can reduce the plasma concentration of low-density lipoprotein cholesterol (LDL-C) by as much as $50 \%$ as well as triglycerides. ${ }^{2}$

Atorvastatin is a potent competitive inhibitor of 3-hydroxy-3-ethylglutarylcoenzyme A (HMG-CoA) reductase, an enzyme that catalyzes conversion of 
HMG-CoA to mevalonate, an early rate-limiting step in cholesterol synthesis. In spite of the beneficial effects of statin treatment in cardiovascular disease prevention, ${ }^{1}$ responses to statin therapy show considerable interindividual variation, ${ }^{3,4}$ and some patients may not achieve sufficient LDL-C reduction even with the most efficacious statins. ${ }^{5}$

Genetic factors are expected to be part of the interindividual variation in the pharmacokinetic and pharmacodynamic response to statins. ${ }^{6,7}$ Various genes encoding for enzymes and transporters that influence pharmacokinetics and the targets of pathways on which a drug acts, as well as those involved in related disease conditions, have been evaluated in candidate gene studies and hypothesis-free genome-wide investigations. ${ }^{6-12}$ Genetic variations on drug transporter genes, $A B C B 1$ and $S L C O 1 B 1$; P450 system genes, $C Y P 3 A 4, C Y P 3 A 5$, and $C Y P 2 D 6$; and other genes encoding lipoproteins and enzymes of lipid metabolic pathways such as $A P O E$ and $H M A C R$, have been suggested to have associations with statin responsiveness. ${ }^{6,8,9}$ Genetic variations that affect pharmacokinetics of statins may modify atorvastatin disposition and hence its efficacy and toxicity., 813 However, the effects of genetic variations have been inconsistently replicated, and there are relatively few data available in Asian populations. ${ }^{14}$ In addition, there are lots of variations in metabolic processes according to statin type, and in the frequency of genetic variations and responsiveness to statins according to ethnic background. ${ }^{6,15}$

Accordingly, we investigated pharmacokinetic and pharmacodynamic changes in healthy Korean individuals after high-dose atorvastatin administration through serial plasma measurements of drug and lipid concentrations. We assessed associations between genetic variations and pharmacokinetics or lipid-lowering effects of atorvastatin using a predesigned gene panel including genes related to absorption, distribution, metabolism, and elimination.

\section{Materials and methods}

\section{Subjects and study design}

This study enrolled 50 healthy Korean male subjects. All subjects were from unrelated families and were ascertained to be healthy by medical history, physical examination, vital signs, electrocardiography, and routine clinical laboratory tests. Subjects were given a single oral dose of $80 \mathrm{mg}$ atorvastatin calcium at 08:00 am with $240 \mathrm{~mL}$ of water in the overnight fasting state. Subjects fasted for 4 hours after atorvastatin administration, then lunch and dinner were served. Venous blood samples for pharmacokinetic analysis were collected via an intravenous catheter at $0,0.25,0.5$,
$0.75,1,1.5,2,3,4,6,8,10,12,24,36$, and 48 hours after dosing. Plasma concentrations of total cholesterol, LDL-C, and triglycerides were measured before and at 24 and 48 hours after atorvastatin administration. Blood sampling for genotyping was performed before drug administration. The study protocol was approved by the Institutional Review Board of Dankook University and Samsung Medical Center, Korea. Written informed consent was obtained from each participant.

\section{Pharmacokinetic and pharmacodynamic measurements}

Plasma concentrations of atorvastatin were determined by liquid chromatography-tandem mass spectrometry (LC-MS/ MS) using a TSQ Quantum Discovery mass spectrometer (Thermo Electron, San Jose, CA, USA). The ion transitions monitored were $\mathrm{m} / \mathrm{z} 559.2 \rightarrow 440$. Pharmacokinetic parameters were determined by BA-Calc software (Korea Food and Drug Administration, Korea) using actual sampling times. Plasma concentrations of the terminal phase were fitted to a log-linear line by the least squares method to obtain the elimination rate constant. The area under the plasma concentration curve from hour 0 to infinity $\left(\mathrm{AUC}_{\infty}\right)$ was calculated using a combination of the trapezoidal rule and extrapolation to infinity by the elimination rate constant. The maximum drug concentration in plasma $\left(\mathrm{C}_{\max }\right)$ and time to $\mathrm{C}_{\max }\left(\mathrm{t}_{\max }\right)$ were determined from observed values. Clearance $(\mathrm{CL})$ of atorvastatin was adjusted according to the body weight of each subject. Plasma lipid concentrations were measured with an Hitachi 7600-110 chemistry analyzer (Hitachi, Tokyo, Japan).

\section{Genotyping}

Genomic DNA was isolated from peripheral blood samples using the Wizard Genomic DNA Purification Kit (Promega, Madison, WI, USA). Genotyping was performed using the Affymetrix drug-metabolizing enzyme and transporter (DMET) Plus array (Affymetrix, Santa Clara, CA, USA), which gauges 1,936 polymorphisms from 225 genes encoding phase I and phase II drug metabolism enzymes as well as drug transporters. ${ }^{16,17}$ Briefly, we determined the yields of pure double-stranded genomic DNA samples before genotyping. Samples were adjusted to concentrations of $60 \mathrm{ng} / \mu \mathrm{L}$. Normalized genomic DNA $(17 \mu \mathrm{L})$ was used as a template for DMET arrays. For loci that had pseudogenes and close homologs, initial genomic amplification using locus-specific primers in a multiplex polymerase chain reaction (mPCR) was performed. By hybridization of highly 
selective molecular inversion probes (MIPs) to their complementary genomic templates, sequences containing polymorphisms of interest were amplified and then fragmented to improve hybridization onto DMET arrays. Hybridized DMET arrays were scanned with an Affymetrix GeneChip Scanner 3000 7G. Genotyping was performed according to the predefined software algorithms of the manufacturer using DMET Console version 1.0. ${ }^{16,18}$

\section{Statistical analyses}

Of 1,936 polymorphisms in 225 genes screened, 519 nonmonomorphic polymorphisms in 181 genes were identified with a $\geq 90 \%$ call rate, $\geq 5 \%$ minor allele frequency, and nonsignificant deviation from Hardy-Weinberg equilibrium $(P \geq 0.001)$. Analysis of variance (ANOVA) or KruskalWallis tests were used to test for associations between genotypes and pharmacokinetic parameters or lipid concentration changes from baseline to 48 hours after atorvastatin administration. Pharmacokinetic parameters included $\mathrm{AUC}_{\infty}$, $\mathrm{C}_{\max }$, and clearance adjusted with body weight $\left(\mathrm{CL}_{\text {adj }}\right)$. An ANOVA test was applied for polymorphisms that satisfied the assumptions of normality and homogeneity of variances in phenotype distribution. A $P$-value less than 0.050 was considered statistically significant. For statistically significant associations, the Jonckheere-Terpstra test was performed to test for ordered differences among genotypes. Corrected $P$-values were obtained using the Benjamini-Hochberg false discovery rate (FDR) approach. Statistical analyses were conducted using R, version 2.9.1 (R Foundation for Statistical Computing, Vienna, Austria), and IBM SPSS Statistics version 18.0 (SPSS Inc., Chicago, IL, USA).

\section{Results}

\section{Participant demographics}

A total of 50 healthy individuals were included in this study. Baseline characteristics are presented in Table 1. All subjects were male with a mean age of 24 years (range, 20-27 years) and a mean body weight of $69 \mathrm{~kg}(50-98$ $\mathrm{kg})$. Mean plasma concentrations of total cholesterol, LDL-C, and triglycerides were $150,72.6$, and $110 \mathrm{mg} / \mathrm{dL}$, retrospectively.

\section{Atorvastatin pharmacokinetics and pharmacodynamics}

Pharmacokinetic properties of atorvastatin are summarized in Table 2. The mean $\mathrm{AUC}_{\infty}, \mathrm{C}_{\max }, \mathrm{t}_{\max }, \mathrm{CL}, \mathrm{CL}_{\text {adj; }}$, and halflife $\left(\mathrm{t}_{1 / 2}\right)$ were $172 \mathrm{ng} \cdot \mathrm{h} / \mathrm{mL}, 36.2 \mathrm{ng} / \mathrm{mL}, 1.07 \mathrm{~h}, 603 \mathrm{~L} / \mathrm{h}$, $8.85 \mathrm{~L} /(\mathrm{h} \cdot \mathrm{kg})$, and $7.75 \mathrm{~h}$, respectively. Pharmacokinetic
Table I Demographics and baseline characteristics $(n=50)$

\begin{tabular}{|c|c|}
\hline Variable & Mean (range) \\
\hline Age (years) & $24(20-27)$ \\
\hline \multicolumn{2}{|l|}{ Gender, n (\%) } \\
\hline Male & $50(100.0)$ \\
\hline Female & $0(0.0)$ \\
\hline Body weight (kg) & $69(50-98)$ \\
\hline \multicolumn{2}{|c|}{ Baseline lipid concentration (mg/dL) } \\
\hline Total cholesterol, n (\%) & $150(10 \mid-212)$ \\
\hline$\geq 200$ & $2(4.0)$ \\
\hline$<200$ & $48(96.0)$ \\
\hline LDL-C, n (\%) & $72.6(42-108)$ \\
\hline$\geq 130$ & $0(0.0)$ \\
\hline$<130$ & $50(100.0)$ \\
\hline Triglycerides, n (\%) & $110(52-233)$ \\
\hline$\geq 150$ & $9(18.0)$ \\
\hline$<150$ & $4 \mathrm{I}(82.0)$ \\
\hline \multicolumn{2}{|l|}{ Genotype, n (\%) } \\
\hline \multicolumn{2}{|l|}{$S L C O|B|$ C. $-9 \mid 0 G>A$} \\
\hline G/G & $33(66.0)$ \\
\hline $\mathrm{G} / \mathrm{A}$ & $14(28.0)$ \\
\hline $\mathrm{A} / \mathrm{A}$ & $3(6.0)$ \\
\hline \multicolumn{2}{|l|}{ SLCOIB3 c.334G $>T$} \\
\hline G/G & $28(56.0)$ \\
\hline $\mathrm{G} / \mathrm{T}$ & $16(32.0)$ \\
\hline$T / T$ & $6(12.0)$ \\
\hline \multicolumn{2}{|l|}{$A B C C 2$ c. $1249 \mathrm{G}>\mathrm{A}$} \\
\hline G/G & $43(86.0)$ \\
\hline $\mathrm{G} / \mathrm{A}$ & $7(14.0)$ \\
\hline
\end{tabular}

Abbreviation: LDL-C, low-density lipoprotein cholesterol.

parameters showed marked interindividual variability, with a coefficient of variation (CV) ranging from $33.3 \%$ to $81.8 \%$. The mean and standard deviation (SD) of the plasma concentration-time profile for atorvastatin after a single oral administration in all participants are shown in Figure 1A. The mean dose-per-body weight normalized $\mathrm{AUC}_{\infty}$ and $\mathrm{C}_{\max }$ were $148 \mathrm{ng} \cdot \mathrm{h} / \mathrm{mL}$ per $\mathrm{mg} / \mathrm{kg}$ and $31.0 \mathrm{ng} / \mathrm{mL}$ per $\mathrm{mg} / \mathrm{kg}$, respectively. The CVs of dose-per-body weight normalized $\mathrm{AUC}_{\infty}$ and $\mathrm{C}_{\max }$ were $59.0 \%$ and $54.4 \%$.

Table 2 Atorvastatin pharmacokinetics in 50 healthy individuals

\begin{tabular}{lllll}
\hline Parameter & Mean & SD & CV & Range \\
\hline $\mathrm{AUC}_{\infty}(\mathrm{ng} \cdot \mathrm{h} / \mathrm{mL})$ & 172 & 94.9 & $55.3 \%$ & $48.9-508.8$ \\
$\mathrm{C}_{\text {max }}(\mathrm{ng} / \mathrm{mL})$ & 36.2 & 19.3 & $53.3 \%$ & $9.5-92.2$ \\
$\mathrm{t}_{\text {max }}(\mathrm{h})$ & 1.07 & 0.89 & $81.8 \%$ & $0.5-4.0$ \\
$\mathrm{CL}(\mathrm{L} / \mathrm{h})$ & 603 & 310 & $51.3 \%$ & $157-\mathrm{I}, 636$ \\
$\mathrm{CL}_{\text {adj }}(\mathrm{L} /(\mathrm{h} \cdot \mathrm{kg}))$ & 8.85 & 4.54 & $51.1 \%$ & $2.5-25.2$ \\
$\mathrm{t}_{1 / 2}(\mathrm{~h})$ & 7.75 & 2.56 & $33.3 \%$ & $2.1-17.0$ \\
\hline
\end{tabular}

Abbreviations: $A \cup C_{\infty}$, area under the plasma concentration curve from hour 0 to infinity; $\mathrm{CL}$, clearance; $\mathrm{CL}_{\mathrm{adj}}$, clearance adjusted with body weight; $\mathrm{C}_{\text {max }}$, maximum drug concentration in plasma; CV, coefficient of variation; SD, standard deviation; $t_{1 / 2}$, half-life; $t_{\text {max }}$, time to $C_{\text {max }}$. 

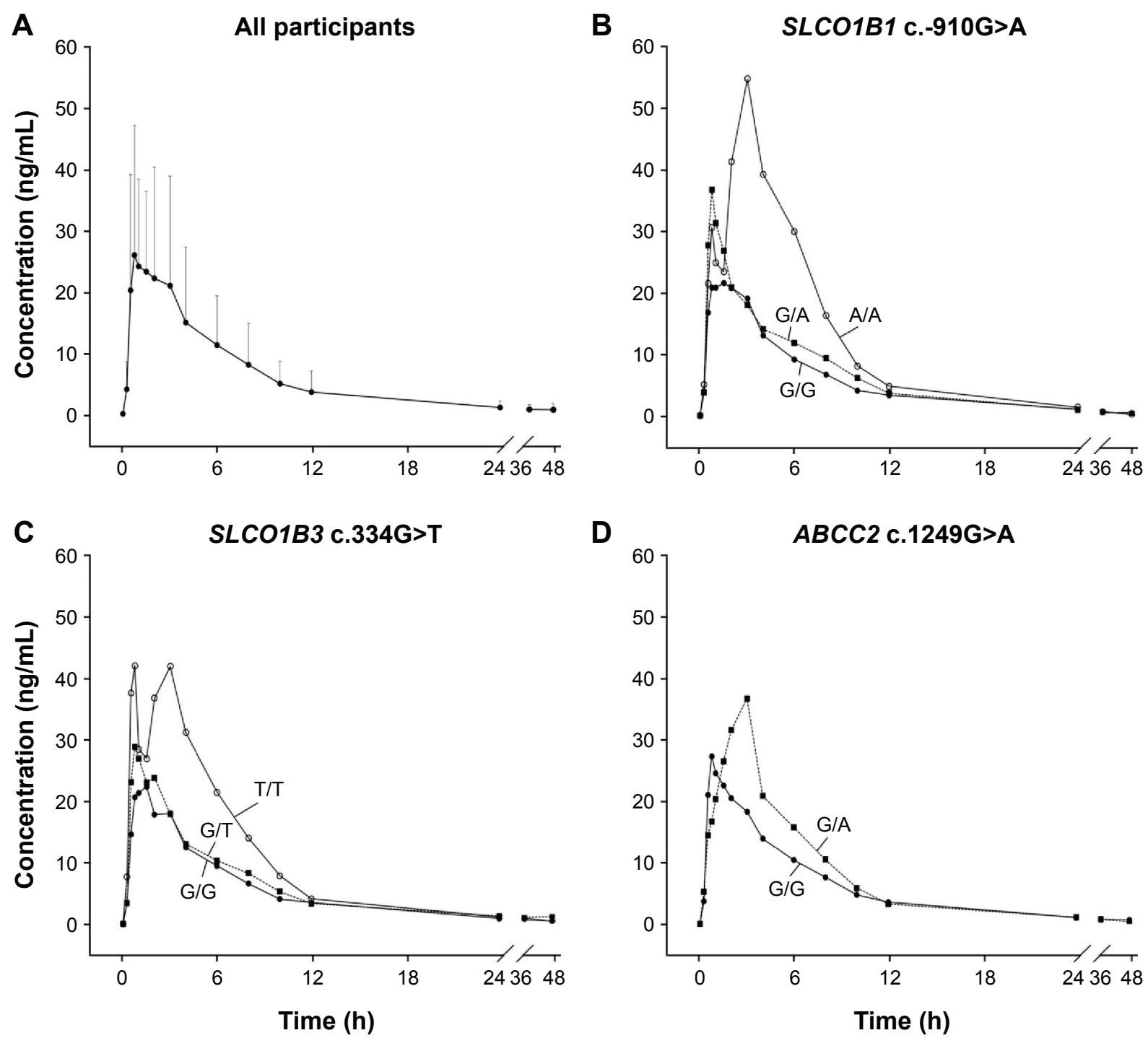

Figure I Plasma concentration vs time curve of atorvastatin in healthy subjects receiving a single dose of $80 \mathrm{mg}$ atorvastatin.

Notes: (A) A plot of all participants. Solid circles represent mean concentrations of plasma atorvastatin, and the bars correspond to standard deviations. (B) A plot according to SLCOIBI c.-9I0G > A genotypes. (C) A plot according to SLCOIB3 c.334G > T genotypes. (D) A plot according to ABCC2 c. I249G >A genotypes. Solid circles correspond to mean concentrations of major homozygotes, quadrangles to heterozygotes, and open circles to minor homozygotes.

Lipid concentration changes at 24 and 48 hours from baseline are summarized in Table 3. Mean total cholesterol and LDL-C concentrations at 48 hours after single atorvastatin administration were decreased by $10.2 \%$ and $15.1 \%$, respectively. Triglyceride concentrations did not show any statistically significant change. There was no correlation between baseline plasma concentrations or pharmacokinetic parameters of atorvastatin and changes in lipid concentrations.

\section{Genetic polymorphisms associated with pharmacokinetic/pharmacodynamic variables}

Sixty-four polymorphisms from 47 genes were associated with pharmacokinetic variables or lipid concentration changes according to genotype $(P<0.050$ in ANOVA or Kruskal-Wallis tests; Table S1). Seventeen polymorphisms were associated with $\mathrm{AUC}_{\infty}, 26$ polymorphisms with $\mathrm{C}_{\max }$, and 16 polymorphisms with $\mathrm{CL}_{\text {adj }}$. In terms of a lipid-lowering effect, 16 polymorphisms were associated with LDL-C, and 12 polymorphisms with total cholesterol. The 13 genes related to variance in LDL-C lowering included $A B C B 11, A B C C 1$, ABCC2, AHR, CBR1, CYP19A1, CYP1B1, CYP4F11, NAT2, SLC10A2, SLC5A6, SLC7A8, and SULT1B1.

Among these 64 polymorphisms, 3 in the SLCO1B1, $S L C O 1 B 3$, and $A B C C 2$ genes showed ordinal associations with $\mathrm{C}_{\max }$, or changes in total cholesterol or LDL-C (Tables 4 and S2). The mean of the plasma concentrationtime profile for atorvastatin according to each genotype is 


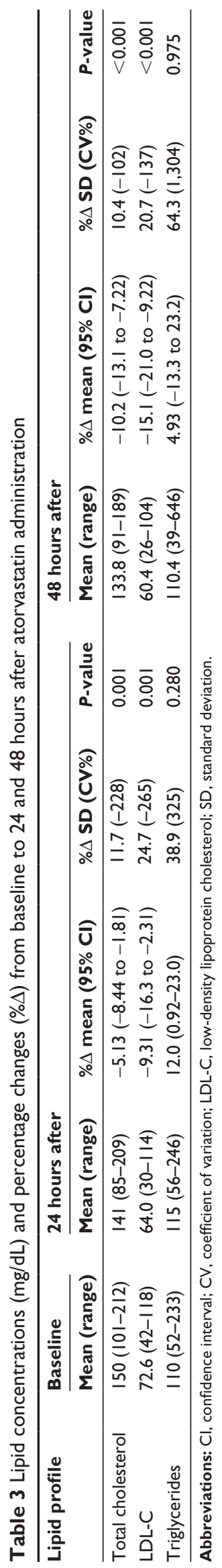

shown in Figure 1B-D. For c.-910G $>$ A (rs4149015) in the SLCO1B1 gene, 33 subjects were G/G homozygotes, 14 were G/A heterozygotes, and 3 were $\mathrm{A} / \mathrm{A}$ homozygotes. The mean $\mathrm{C}_{\max }$ was $76.5 \mathrm{ng} / \mathrm{mL}$ for $\mathrm{A} / \mathrm{A}, 34.0 \mathrm{ng} / \mathrm{mL}$ for $\mathrm{G} / \mathrm{A}$, and $33.5 \mathrm{ng} / \mathrm{mL}$ for $\mathrm{G} / \mathrm{G}$ (Figure 2). In the analysis of haplotypes that included rs4149015, carriers possessing the SLCO1B1*17 variant allele (rs2306283, rs4149056, and rs4149015) showed higher $\mathrm{C}_{\max }$ and $\mathrm{AUC}_{\infty}$ compared to noncarriers ( 46.1 vs $32.8 \mathrm{ng} / \mathrm{mL}, P=0.032$ for $\mathrm{C}_{\max } ; 222 \mathrm{vs}$ $154 \mathrm{ng} / \mathrm{mL}, P=0.026$ for $\mathrm{AUC}_{\infty}$ ). The $S L C O 1 B 3 \mathrm{c} .334 \mathrm{G}>\mathrm{T}$ (p.Ala112Ser, rs4149117) also influenced the $\mathrm{C}_{\max }$ of atorvastatin. Mean $\mathrm{C}_{\max }$ for 6 subjects with $\mathrm{T} / \mathrm{T}(63.0 \mathrm{ng} / \mathrm{mL})$ was higher than that in 16 with $\mathrm{G} / \mathrm{T}(34.7 \mathrm{ng} / \mathrm{mL})$ and 28 with $\mathrm{G} / \mathrm{G}(31.4 \mathrm{ng} / \mathrm{mL}$, FDR $P=0.037)$. In genotype combination analysis of $S L C O 1 B 1$ c.-910G $>$ A and $S L C O 1 B 3$ c.334G $>$ T, major homozygous individuals of both polymorphisms showed the lowest mean $\mathrm{C}_{\max }(30.7 \mathrm{ng} / \mathrm{mL})$, and the $\mathrm{C}_{\max }$ tended to increase according to the increase in the number of minor alleles ( $P=0.011$, Figure 3$) ; 39.3 \mathrm{ng} / \mathrm{mL}$ for 1 minor allele, $29.0 \mathrm{ng} / \mathrm{mL}$ for 2 minor alleles, $56.0 \mathrm{ng} / \mathrm{mL}$ for 3 minor alleles, and 76.5 for 4 minor alleles. $A B C C 2$ c. $1249 \mathrm{G}>\mathrm{A}$ (p.Val417Ile, rs2273697) was associated with changes in total cholesterol and LDL-C at 48 hours after atorvastatin administration. In particular, the decrease in total cholesterol and LDL-C was smaller in those with G/A $(n=7)$ than in the 43 subjects with $\mathrm{G} / \mathrm{G}$. There was no A/A homozygote identified. The mean percentage changes in total cholesterol and LDL-C in subjects with G/A were $0.23 \%$ and $-0.70 \%$, compared to $-11.9 \%$ and $-17.4 \%$ for those with $\mathrm{G} / \mathrm{G}$.

\section{Discussion}

This study investigated pharmacokinetic characteristics and lipid-lowering response following high-dose atorvastatin treatment in young, healthy Korean males in association with genotypes in genes related to absorption, distribution, metabolism, and elimination of drugs.

Statins are known to produce immediate biochemical changes. ${ }^{19,20}$ We showed that atorvastatin achieved $\mathrm{C}_{\max }$ at around 1.07 hours. Dose-per-body weight normalized $\mathrm{AUC}_{\infty}$ and $\mathrm{C}_{\max }$ were comparable to the results from previous studies in Asians and Caucasians. ${ }^{14}$ Interindividual variability of pharmacokinetic parameters was observed in spite of the uniformity of the enrolled subjects, who were all young and healthy males, and controlled conditions. This finding suggests that much of the pharmacokinetic variability is caused by innate or underlying conditions such as genetic factors and the gut microbiome, instead of controllable environmental factors such as concomitant medicines and compliance. 
Table 4 Genetic polymorphisms associated with pharmacokinetic parameters and lipid-lowering response

\begin{tabular}{|c|c|c|c|c|c|c|c|c|c|c|}
\hline \multirow[t]{2}{*}{ Gene } & \multirow[t]{2}{*}{ rs no } & \multirow{2}{*}{$\begin{array}{l}\text { Nucleotide } \\
\text { change }\end{array}$} & \multirow[t]{2}{*}{ MAF } & \multirow[t]{2}{*}{ Variable } & \multicolumn{3}{|l|}{ Mean } & \multirow[t]{2}{*}{ Unit } & \multirow[t]{2}{*}{$P$-value } & \multirow[t]{2}{*}{ FDR $P$} \\
\hline & & & & & $\mathbf{A} / \mathbf{A}^{\mathrm{a}}$ & A/B & $B / B$ & & & \\
\hline SLCOIBI & rs4l490I5 & c. $-910 \mathrm{G}>\mathrm{A}$ & 0.177 & $\mathrm{C}_{\max }$ & 33.5 & 34.0 & 76.5 & $\mathrm{ng} / \mathrm{mL}$ & 0.021 & 0.040 \\
\hline SLCOIB3 & rs4l49II7 & c. $334 \mathrm{G}>\mathrm{T}$ & 0.310 & $\mathrm{C}_{\max }$ & 31.4 & 34.7 & 63.0 & $\mathrm{ng} / \mathrm{mL}$ & 0.010 & 0.037 \\
\hline \multirow[t]{2}{*}{$A B C C 2$} & rs2273697 & c. $1249 \mathrm{G}>\mathrm{A}$ & 0.113 & $\% \Delta \mathrm{TC}$ & -11.9 & 0.23 & - & $\%$ & 0.003 & 0.019 \\
\hline & & & & $\% \Delta$ LDL-C & -17.4 & -0.70 & - & $\%$ & 0.023 & 0.048 \\
\hline
\end{tabular}

Notes: ${ }^{a} \mathrm{~A} / \mathrm{A}$, major homozygote; $\mathrm{A} / \mathrm{B}$, heterozygotes; $\mathrm{B} / \mathrm{B}$, minor heterozygotes.

Abbreviations: $\mathrm{C}_{\text {max }}$, maximum drug concentration in plasma; FDR, false discovery rate; \% $\Delta$ LDL-C, percentage change in low-density lipoprotein cholesterol from baseline to 48 hours after atorvastatin administration; MAF, minor allele frequency; $\% \Delta \mathrm{TC}$, percentage change in total cholesterol from baseline to 48 hours after atorvastatin administration.
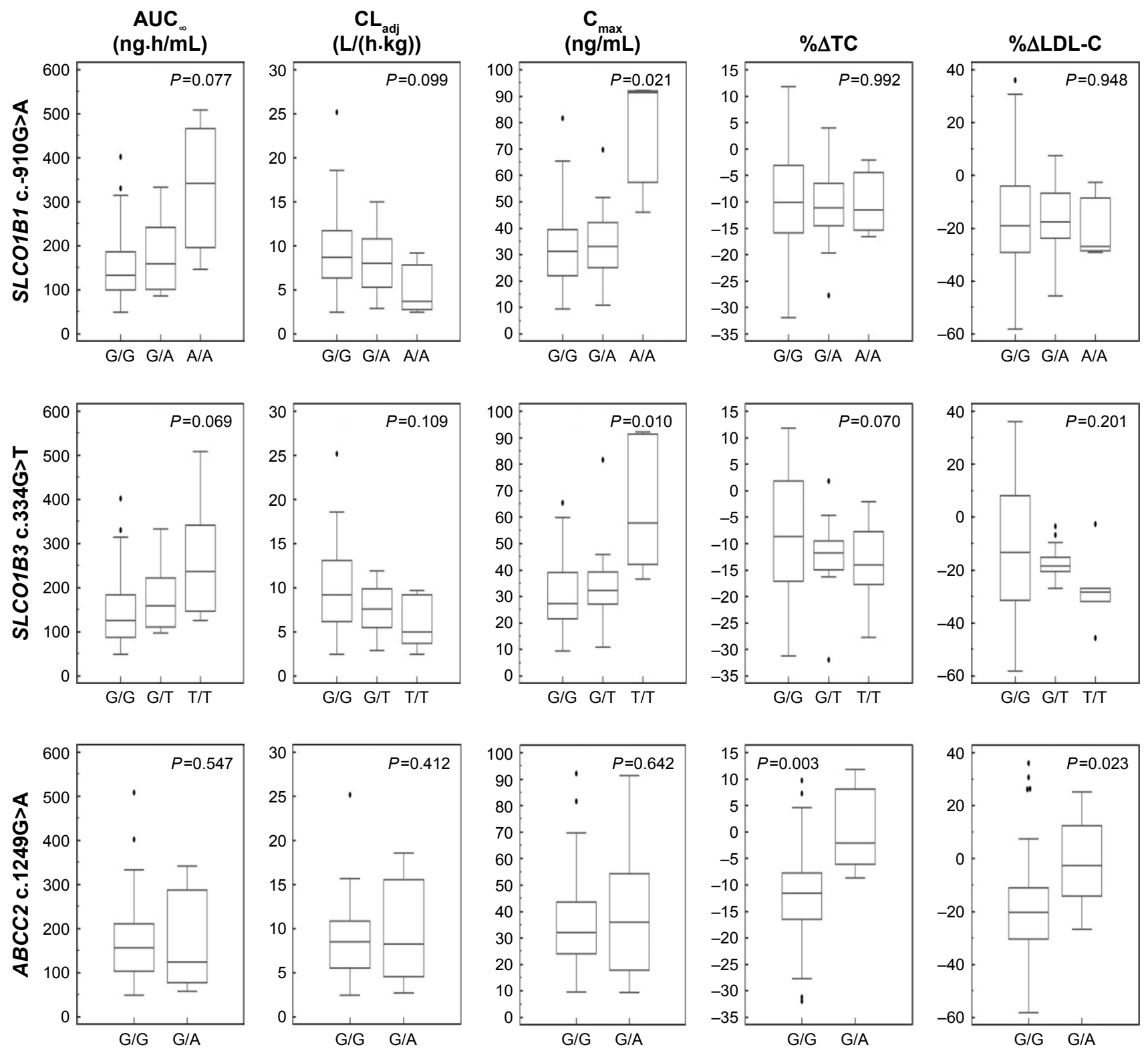

Figure 2 The pharmacodynamic and pharmacokinetic differences according to each genotype of SLCOIBI c.-9I0G >A, SLCOIB3 c.334G >T, and ABCC2 c.I249G >A. Notes: The box-and-whisker plots of the area under the plasma concentration curve from hour 0 to infinity $\left(A \cup C_{\infty}\right)$, clearance adjusted with body weight $\left(\mathrm{CL}_{\text {adj }}\right)$ and maximum concentration $\left(C_{\max }\right)$ of atorvastatin, and percentage changes in total cholesterol (\% $\left.\Delta \mathrm{TC}\right)$ and LDL-C (\% $\left.\Delta \mathrm{LDL}-\mathrm{C}\right)$ from baseline to 48 hours after atorvastatin administration according to genetic polymorphisms, are presented. There were differences in $C_{\max }$ according to SLCOIBI c.-9I0G $>$ A and SLCOIB3 c.334G $>$ T genotypes, and $\% \Delta T C$ and $\% \Delta L D L-C$ between G/G and G/A genotypes of $A B C C 2$ c. I249G $>$ A. 


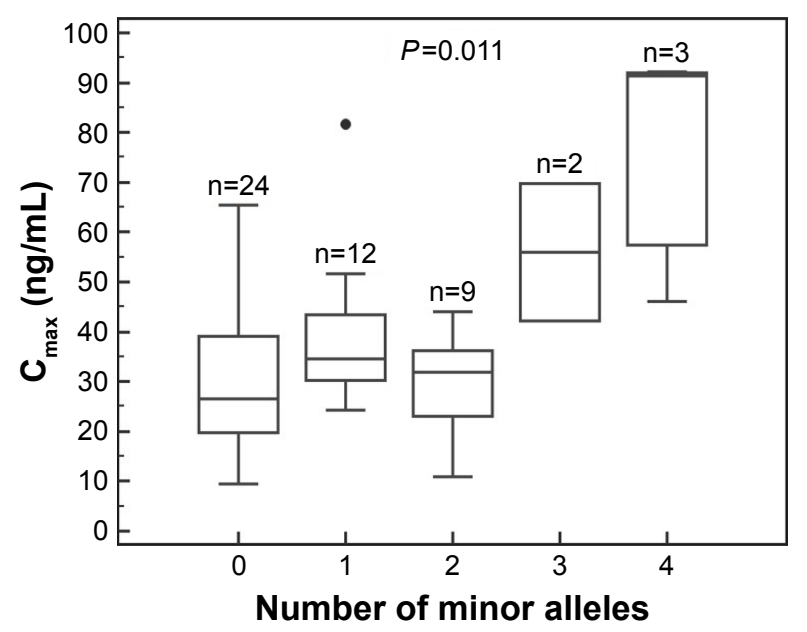

Figure 3 The maximum concentration $\left(C_{\max }\right)$ of atorvastatin according to the genotype combination of SLCOIBI c.-9I0G > A and SLCOIB3 c.334G > T.

The lipid-lowering effect of atorvastain also showed interindividual variation. In agreement with previous studies, there were no pharmacokinetic parameters associated with the lipid-lowering effect of atorvastatin. ${ }^{19,20}$

Because the pharmacokinetic and pharmacodynamic changes in this study were as expected, we next inspected their association with multiple genetic polymorphisms. Polymorphisms in the SLCO1B1, SLCO1B3, and $A B C C 2$ genes were ordinally associated with pharmacokinetic properties or lipid-lowering responses. SLCO1B1 c.-910G $>$ A, identified in 17 subjects, was associated with $\mathrm{C}_{\max }$, and the SLCO1B1*17 haplotype including this polymorphism was also related to $\mathrm{C}_{\max }$ and $\mathrm{AUC}_{\infty}$. The $\mathrm{S} L C O 1 B 1$ gene encodes the organic anion transporting polypeptide (OATP) 1B1, which facilitates hepatic uptake of statins on the sinusoidal membrane of hepatocytes. ${ }^{21,22}$ Variations in SLCO1B1, c. $-910 \mathrm{G}>\mathrm{A}$ and c.521T $>\mathrm{C}$ (rs4149056), and haplotypes, $* 5$, $* 15$, and $* 17$, have been reported to be associated with pharmacokinetic and lipid-lowering responses in previous studies. ${ }^{6-8,23}$ In addition, a loss-of-function variation, c.521T $>C$, which reduced liver influx of the statins, has a potent effect on myalgia, one adverse effect of statins. ${ }^{8}$ Similar findings have been reported in individuals who received atorvastatin, including Asians. , $^{84,25}$

$S L C O 1 B 3$ c. $334 \mathrm{G}>\mathrm{T}$ was associated with a higher $\mathrm{C}_{\max }$ in this study. The OATP 1B3 encoded by the SLCO1B3 gene is one of the major hepatic OATPs and has a potent function as an active transporter of atorvastatin, following the OATP $1 \mathrm{~B} 1{ }^{26,27}$ Several genetic polymorphisms in the SLCO1B3 gene have been investigated in previous in vitro studies. ${ }^{28,29}$ A preclinical study showed no effect of c.334G $>$ T on cellular uptake of atorvastatin, ${ }^{28}$ which suggests the minor effect of the
SLCO1B3 gene on the distribution of atorvastatin. As previous studies suggested the aggregate effect of top-associated polymorphisms, ${ }^{30,31}$ we evaluated the genotype combination effect. We observed the genotype combination effect of $S L C O 1 B 1$ c. $-910 \mathrm{G}>\mathrm{A}$ and $S L C O 1 B 3$ c.334G $>$ T; thus, further in vivo analysis of the role of transporter enzymes on the metabolism of statins is needed to clarify the interaction.

c. $1249 \mathrm{G}>\mathrm{A}$ in the $A B C C 2$ gene was associated with a small lipid-lowering response in this study. Multidrug resistance-associated protein 2 (MRP2/ABCC2) is an efflux transporter expressed in various types of cells, including hepatocytes, enterocytes, and proximal renal tubular cells, ${ }^{32}$ and plays an important role in reducing gastrointestinal absorption and facilitating the biliary and urinary excretion of its substrates, including pravastatin and fluvastatin. ${ }^{32-34}$ A polymorphism in the $A B C C 2$ gene has been related to low plasma concentrations of pravastatin, ${ }^{33}$ as well as dose decreases or switches to other cholesterol-lowering agents during simvastatin and atorvastatin therapy. ${ }^{35}$ In addition, after atorvastatin administration, mRNA levels of transporters, including MRP2/ABCC2, are downregulated and positively correlated with the percentage of reduction in LDL-C. ${ }^{36}$ Collectively, these data indicate that the $A B C C 2$ gene might affect the lipid-lowering response to atorvastatin treatment.

In this prospective study, we performed a pharmacokinetic and pharmacodynamic analysis in healthy Korean individuals following high-dose atorvastatin administration. However, we should acknowledge the limitation of our study. Because of the relatively small sample size, some associations may have been missed or noticed only by chance, and also the aggregate effect of polymorphisms was partially evaluated. Our study findings should be confirmed through future large prospective studies in various ethnic populations. The strength of our study is that we provided prospective data about pharmacokinetics and the lipid-lowering response after atorvastatin $80 \mathrm{mg}$ administration for a hypothesis-free genetic association study in healthy, young male Asian subjects; a population that has not been studied in this context before. ${ }^{25}$ Our findings support the value of further studies investigating factors that affect interindividual atorvastatin treatment variability, such as genes related to pharmacodynamics, and the contribution to the risk of adverse effects of polymorphisms identified as associated with the $\mathrm{C}_{\max }$ of atorvastatin.

\section{Conclusion}

In conclusion, we genotyped multiple polymorphisms in genes related to phase I and II drug metabolism enzymes and drug transporters, and evaluated the association of these 
with pharmacokinetic properties and lipid-lowering response following atorvastatin administration. Our findings describe pharmacokinetic and pharmacodynamic changes with variations among individuals after high-dose atorvastatin treatment in healthy Korean subjects. We also identified various genetic polymorphisms related to the response to atorvastatin treatment, including the association between polymorphisms in the transporter genes, $S L C O 1 B 1, S L C O 1 B 3$, and $A B C C 2$, and either $\mathrm{C}_{\max }$ of atorvastatin or lipid-lowering response. These findings contribute to the understanding of interindividual variation in atorvastatin treatment.

\section{Acknowledgments}

We thank Hyung-Gun Kim (Department of Pharmacology, Dankook University) for his contribution in performing the clinical experiments and pharmacokinetic analysis. This research was supported by a grant (HI13C2098) from Korea Health Technology R\&D Project through the Korea Health Industry Development Institute (KHIDI) funded by the Ministry of Health \& Welfare, Republic of Korea.

\section{Disclosure}

The authors report no conflicts of interest in this work.

\section{References}

1. Stone NJ, Robinson JG, Lichtenstein AH, et al. 2013 ACC/AHA guideline on the treatment of blood cholesterol to reduce atherosclerotic cardiovascular risk in adults: a report of the American College of Cardiology/American Heart Association Task Force on Practice Guidelines. J Am Coll Cardiol. 2014;63(25 Pt B):2889-2934.

2. Mangravite LM, Thorn CF, Krauss RM. Clinical implications of pharmacogenomics of statin treatment. Pharmacogenomics J. 2006;6(6): 360-374.

3. Bousoula E, Kolovou V, Perrea D, Kolovou G. Pharmacogenetics and statin treatment: reality or theory? Curr Vasc Pharmacol. 2015;13(5): 616-623.

4. Colhoun HM, Betteridge DJ, Durrington PN, et al. Primary prevention of cardiovascular disease with atorvastatin in type 2 diabetes in the Collaborative Atorvastatin Diabetes Study (CARDS): multicentre randomised placebo-controlled trial. Lancet. 2004;364(9435):685-696.

5. LaRosa JC. Low-density lipoprotein cholesterol reduction: the end is more important than the means. Am J Cardiol. 2007;100(2):240-242.

6. Kajinami K, Akao H, Polisecki E, Schaefer EJ. Pharmacogenomics of statin responsiveness. Am J Cardiol. 2005;96(9A):65K-70K; discussion $34 \mathrm{~K}-35 \mathrm{~K}$.

7. Chasman DI, Giulianini F, MacFadyen J, Barratt BJ, Nyberg F, Ridker PM. Genetic determinants of statin-induced low-density lipoprotein cholesterol reduction: the Justification for the Use of Statins in Prevention: an Intervention Trial Evaluating Rosuvastatin (JUPITER) trial. Circ Cardiovasc Genet. 2012;5(2):257-264.

8. Sirtori CR, Mombelli G, Triolo M, Laaksonen R. Clinical response to statins: mechanism(s) of variable activity and adverse effects. Ann Med. 2012;44(5):419-432.

9. Hopewell JC, Parish S, Offer A, et al. Impact of common genetic variation on response to simvastatin therapy among 18705 participants in the Heart Protection Study. Eur Heart J. 2013;34(13):982-992.
10. Deshmukh HA, Colhoun HM, Johnson T, et al. Genome-wide association study of genetic determinants of LDL-c response to atorvastatin therapy: importance of Lp(a). J Lipid Res. 2012;53(5):1000-1011.

11. Barber MJ, Mangravite LM, Hyde CL, et al. Genome-wide association of lipid-lowering response to statins in combined study populations. PLoS One. 2010;5(3):e9763.

12. Thompson JF, Hyde CL, Wood LS, et al. Comprehensive wholegenome and candidate gene analysis for response to statin therapy in the Treating to New Targets (TNT) cohort. Circ Cardiovasc Genet. 2009; 2(2):173-181.

13. Rodrigues AC, Hirata MH, Hirata RD. The genetic determinants of atorvastatin response. Curr Opin Mol Ther. 2007;9(6):545-553.

14. Gandelman K, Fung GL, Messig M, Laskey R. Systemic exposure to atorvastatin between Asian and Caucasian subjects: a combined analysis of 22 studies. Am J Ther. 2012;19(3):164-173.

15. Liao JK. Safety and efficacy of statins in Asians. Am J Cardiol. 2007; 99(3):410-414.

16. Burmester JK, Sedova M, Shapero MH, Mansfield E. DMET microarray technology for pharmacogenomics-based personalized medicine. Methods Mol Biol. 2010;632:99-124.

17. Hu Y, Ehli EA, Nelson K, et al. Genotyping performance between saliva and blood-derived genomic DNAs on the DMET array: a comparison. PLoS One. 2012;7(3):e33968.

18. Daly TM, Dumaual CM, Miao X, et al. Multiplex assay for comprehensive genotyping of genes involved in drug metabolism, excretion, and transport. Clin Chem. 2007;53(7):1222-1230.

19. Lennernas H. Clinical pharmacokinetics of atorvastatin. Clin Pharmacokinet. 2003;42(13):1141-1160.

20. Stern RH, Yang BB, Hounslow NJ, MacMahon M, Abel RB, Olson SC. Pharmacodynamics and pharmacokinetic-pharmacodynamic relationships of atorvastatin, an HMG-CoA reductase inhibitor. $J$ Clin Pharmacol. 2000;40(6):616-623.

21. Ho RH, Kim RB. Transporters and drug therapy: implications for drug disposition and disease. Clin Pharmacol Ther. 2005;78(3):260-277.

22. Hsiang B, Zhu Y, Wang Z, et al. A novel human hepatic organic anion transporting polypeptide (OATP2). Identification of a liver-specific human organic anion transporting polypeptide and identification of rat and human hydroxymethylglutaryl-CoA reductase inhibitor transporters. J Biol Chem. 1999;274(52):37161-37168.

23. Niemi M, Schaeffeler E, Lang T, et al. High plasma pravastatin concentrations are associated with single nucleotide polymorphisms and haplotypes of organic anion transporting polypeptide-C (OATP-C, SLCO1B1). Pharmacogenetics. 2004;14(7):429-440.

24. Morimoto K, Oishi T, Ueda S, Ueda M, Hosokawa M, Chiba K. A novel variant allele of OATP-C (SLCO1B1) found in a Japanese patient with pravastatin-induced myopathy. Drug Metab Pharmacokinet. 2004; 19(6):453-455.

25. Lee YJ, Lee MG, Lim LA, Jang SB, Chung JY. Effects of SLCO1B1 and $\mathrm{ABCB} 1$ genotypes on the pharmacokinetics of atorvastatin and 2-hydroxyatorvastatin in healthy Korean subjects. Int J Clin Pharmacol Ther. 2010;48(1):36-45.

26. Vildhede A, Karlgren M, Svedberg EK, et al. Hepatic uptake of atorvastatin: influence of variability in transporter expression on uptake clearance and drug-drug interactions. Drug Metab Dispos. 2014;42(7): $1210-1218$

27. Kunze A, Huwyler J, Camenisch G, Poller B. Prediction of organic anion-transporting polypeptide 1B1- and 1B3-mediated hepatic uptake of statins based on transporter protein expression and activity data. Drug Metab Dispos. 2014;42(9):1514-1521.

28. Schwarz UI, Meyer zu Schwabedissen HE, Tirona RG, et al. Identification of novel functional organic anion-transporting polypeptide 1B3 polymorphisms and assessment of substrate specificity. Pharmacogenet Genomics. 2011;21(3):103-114.

29. DeGorter MK, Ho RH, Leake BF, Tirona RG, Kim RB. Interaction of three regiospecific amino acid residues is required for OATP1B1 gain of OATP1B3 substrate specificity. Mol Pharm. 2012;9(4):986-995. 
30. Derringer J, Krueger RF, Dick DM, et al. The aggregate effect of dopamine genes on dependence symptoms among cocaine users: crossvalidation of a candidate system scoring approach. Behav Genet. 2012; 42(4):626-635.

31. Ferrari M, Guasti L, Maresca A, et al. Association between statin-induced creatine kinase elevation and genetic polymorphisms in SLCO1B1, ABCB1 and ABCG2. Eur J Clin Pharmacol. 2014;70(5):539-547.

32. Gerk PM, Vore M. Regulation of expression of the multidrug resistance-associated protein 2 (MRP2) and its role in drug disposition. J Pharmacol Exp Ther. 2002;302(2):407-415.

33. Niemi M, Arnold KA, Backman JT, et al. Association of genetic polymorphism in ABCC2 with hepatic multidrug resistance-associated protein 2 expression and pravastatin pharmacokinetics. Pharmacogenet Genomics. 2006;16(11):801-808.
34. Lindahl A, Sjoberg A, Bredberg U, Toreson H, Ungell AL, Lennernas H. Regional intestinal absorption and biliary excretion of fluvastatin in the rat: possible involvement of mrp2. Mol Pharm. 2004;1(5):347-356.

35. Becker ML, Elens LL, Visser LE, et al. Genetic variation in the ABCC2 gene is associated with dose decreases or switches to other cholesterol-lowering drugs during simvastatin and atorvastatin therapy. Pharmacogenomics J. 2013;13(3):251-256.

36. Rodrigues $\mathrm{AC}$, Hirata $\mathrm{MH}$, Hirata RD. Impact of cholesterol on $\mathrm{ABC}$ and SLC transporters expression and function and its role in disposition variability to lipid-lowering drugs. Pharmacogenomics. 2009;10(6):1007-1016. 


\section{Supplementary materials}

Table SI Genotypes associated with atorvastatin pharmacokinetics and lipid-lowering response

\begin{tabular}{|c|c|c|c|c|c|c|c|c|}
\hline Category & Gene & rs number & Nucleotide (AA) change & Call rate $(\%)$ & MAF & Major/minor allele & Associated variable & $P$-value \\
\hline \multirow[t]{27}{*}{ Phase I } & ADH6 & rsl0002894 & c. $-93 \mid C>T$ & 98.3 & 0.155 & $\mathrm{~T} / \mathrm{C}$ & $\mathrm{C}_{\max }$ & 0.028 \\
\hline & $A L D H 2$ & rs67I & c.1369G > A (p.Glu504Lys) & 100 & 0.076 & $\mathrm{G} / \mathrm{A}$ & $\mathrm{CL}_{\text {adj }}$ & 0.010 \\
\hline & $A L D H 3 A I$ & rs2072330 & c.74IT >A (p.Pro247=) & 96.6 & 0.342 & T/A & $\mathrm{C}_{\max }$ & 0.015 \\
\hline & CBRI & rs 1005695 & c. $397+2$ I0G $>C$ & 98.3 & 0.379 & $\mathrm{G} / \mathrm{C}$ & $\% \Delta \mathrm{TC}$ & 0.011 \\
\hline & & & & & & & $\% \Delta \mathrm{LDL}-\mathrm{C}$ & 0.005 \\
\hline & & rs998383 & c. $* 559 \mathrm{C}>\mathrm{G}$ & 100 & 0.356 & $\mathrm{C} / \mathrm{G}$ & $\% \Delta \mathrm{TC}$ & 0.011 \\
\hline & & & & & & & $\% \Delta \mathrm{LDL}-\mathrm{C}$ & 0.005 \\
\hline & CYPIBI & rs 1056837 & c. 1347T > C (p.Asp449=) & 100 & 0.127 & $\mathrm{C} / \mathrm{T}$ & $\% \Delta \mathrm{LDL}-\mathrm{C}$ & 0.048 \\
\hline & CYP2B6 & rs2279344 & c. $822+\mid 83 G>A$ & 100 & 0.395 & $A / G$ & $\mathrm{CL}_{\text {adj }}$ & 0.046 \\
\hline & CYP2EI & rs38I3867 & C. $-1295 G>C$ & 100 & 0.234 & $\mathrm{G} / \mathrm{C}$ & $\mathrm{C}_{\max }$ & 0.024 \\
\hline & & rs2031920 & c. $-1055 C>T$ & 100 & 0.218 & $\mathrm{C} / \mathrm{T}$ & $\mathrm{C}_{\max }$ & 0.040 \\
\hline & CYP4F2 & rs2074900 & c. $1029 \mathrm{C}>\mathrm{T}$ (p.His343=) & 100 & 0.169 & $\mathrm{C} / \mathrm{T}$ & $\mathrm{C}_{\max }$ & 0.024 \\
\hline & CYP4F8 & rs42396I4 & c. $* 52 C>T$ & 98.3 & 0.224 & $\mathrm{~T} / \mathrm{C}$ & $A \cup C_{\infty}$ & 0.049 \\
\hline & & & & & & & $\mathrm{C}_{\max }$ & 0.032 \\
\hline & CYP4FII & rs3765070 & c. $318 \mathrm{~T}>\mathrm{C}$ (p.Ile $106=)$ & 100 & 0.424 & $\mathrm{~T} / \mathrm{C}$ & $\% \Delta \mathrm{LDL}-\mathrm{C}$ & 0.019 \\
\hline & & rs 1060463 & c.I336G >A (p.Asp446Asn) & 100 & 0.407 & $\mathrm{G} / \mathrm{A}$ & $\% \Delta \mathrm{LDL}-\mathrm{C}$ & 0.019 \\
\hline & CYPIIBI & rs4534 & c. $128 \mathrm{G}>\mathrm{A}(\mathrm{p} . \mathrm{Arg} 43 \mathrm{Gln})$ & 100 & 0.381 & $\mathrm{G} / \mathrm{A}$ & $A \cup C_{\infty}$ & 0.027 \\
\hline & & & & & & & $\mathrm{C}_{\max }$ & 0.047 \\
\hline & & & & & & & $\mathrm{CL}_{\mathrm{adj}}$ & 0.038 \\
\hline & CYPIIB2 & rs4536 & c.873G >A (p.Ala29I=) & 100 & $0.44 I$ & $A / G$ & $A \cup C_{\infty}$ & 0.010 \\
\hline & & & & & & & $\mathrm{CL}_{\text {adj }}$ & 0.010 \\
\hline & CYPI9AI & rs7005I9 & c.790C > T (p.Arg264Cys) & 100 & 0.136 & $\mathrm{C} / \mathrm{T}$ & $\% \Delta \mathrm{LDL}-\mathrm{C}$ & 0.031 \\
\hline & & rs4646 & c. $*|6| T>G$ & 100 & 0.093 & $\mathrm{G} / \mathrm{A}$ & $\mathrm{AUC}_{\infty}$ & 0.010 \\
\hline & $E P H X I$ & rsI05I740 & c.337T>C (p.Tyr I I3His) & 100 & 0.373 & $\mathrm{~T} / \mathrm{C}$ & $\mathrm{CL}_{\mathrm{adj}}$ & 0.012 \\
\hline & FMO3 & rsI736557 & c.769G >A (p.Val257Met) & 98.3 & 0.129 & $\mathrm{G} / \mathrm{A}$ & $\mathrm{C}_{\max }$ & 0.026 \\
\hline & & rs2266780 & c.923A > G (p.Glu308Gly) & 100 & 0.203 & $A / G$ & $\mathrm{CL}_{\text {adj }}$ & 0.014 \\
\hline & & & & & & & $\% \Delta \mathrm{TC}$ & 0.031 \\
\hline \multirow[t]{23}{*}{ Phase II } & CHSTIO & rs4l4952I & c.*39T $>C$ & 100 & 0.059 & $\mathrm{~T} / \mathrm{C}$ & $\mathrm{AUC}_{\infty}$ & 0.029 \\
\hline & & & & & & & $\mathrm{C}_{\max }$ & 0.007 \\
\hline & & & & & & & $\% \Delta \mathrm{TC}$ & 0.007 \\
\hline & CHSTI3 & rs3856650 & c. $97+3926 \mathrm{~T}>\mathrm{A}$ & 98.3 & 0.267 & T/A & $A \cup C_{\infty}$ & 0.019 \\
\hline & & & & & & & $\mathrm{C}_{\max }$ & 0.003 \\
\hline & & & & & & & $\mathrm{CL}_{\text {adj }}$ & 0.043 \\
\hline & & rs430538I & c. $98-5237 A>C$ & 98.3 & 0.216 & $\mathrm{~A} / \mathrm{C}$ & $\mathrm{C}_{\max }$ & 0.045 \\
\hline & & & & & & & $\% \Delta \mathrm{TC}$ & 0.034 \\
\hline & & rsI873397 & c. $180+2676 C>G$ & 100 & 0.229 & $\mathrm{G} / \mathrm{C}$ & $\mathrm{C}_{\max }$ & 0.007 \\
\hline & GSTA3 & rs5I2795 & c. $272+|6| A>G$ & 100 & 0.339 & $A / G$ & $\mathrm{C}_{\max }$ & 0.045 \\
\hline & GSTA4 & rs367836 & c. $* 137 \mathrm{C}>\mathrm{A}$ & 98.3 & 0.172 & $\mathrm{~A} / \mathrm{C}$ & $\% \Delta \mathrm{TC}$ & 0.010 \\
\hline & NAT2 & rsI79993I & c.857G >A (p.Gly286Glu) & 100 & 0.144 & $\mathrm{G} / \mathrm{A}$ & $\% \Delta \mathrm{TC}$ & 0.030 \\
\hline & & & & & & & $\% \Delta \mathrm{LDL}-\mathrm{C}$ & 0.047 \\
\hline & SULTIBI & rsll731028 & c. $376-2858 \mathrm{G}>\mathrm{A}$ & 100 & 0.220 & $\mathrm{G} / \mathrm{A}$ & $\% \Delta \mathrm{LDL}-\mathrm{C}$ & 0.037 \\
\hline & SULTIC2 & rs17036104 & c.796T > G (p.Ser266Ala) & 96.6 & 0.105 & T/G & $A \cup C_{\infty}$ & 0.006 \\
\hline & & & & & & & $\mathrm{CL}_{\text {adj }}$ & 0.007 \\
\hline & UGT2B4 & rsl966I5I & c. $* 225 \mathrm{~T}>\mathrm{C}$ & 94.9 & 0.491 & $\mathrm{~T} / \mathrm{C}$ & $\mathrm{AUC}_{\infty}$ & 0.027 \\
\hline & & & & & & & $\mathrm{CL}_{\text {adj }}$ & 0.040 \\
\hline & UGT2BI5 & rs3100 & c. $* 168 \mathrm{C}>\mathrm{T}$ & 100 & 0.212 & $\mathrm{C} / \mathrm{T}$ & $\mathrm{C}_{\max }$ & 0.014 \\
\hline & & rs4l4827I & c.* $185 \mathrm{~A}>\mathrm{T}$ & 98.3 & 0.181 & $\mathrm{~A} / \mathrm{T}$ & $A \cup C_{\infty}$ & 0.045 \\
\hline & & & & & & & $\mathrm{C}_{\max }$ & 0.007 \\
\hline & UGT8 & rs4l48254 & c.677C > T (p.Pro226Leu) & 100 & 0.085 & $\mathrm{C} / \mathrm{T}$ & $\mathrm{AUC}_{\infty}$ & 0.018 \\
\hline & & & & & & & $\mathrm{CL}_{\text {adj }}$ & 0.031 \\
\hline
\end{tabular}


Table SI (Continued)

\begin{tabular}{|c|c|c|c|c|c|c|c|c|}
\hline Category & Gene & rs number & Nucleotide (AA) change & Call rate (\%) & MAF & Major/minor allele & Associated variable & $P$-value \\
\hline \multirow[t]{29}{*}{ Transporter } & $A B C B I$ & rs 10276036 & c. $1000-44 G>A$ & 98.4 & 0.451 & $\mathrm{G} / \mathrm{A}$ & $\mathrm{AUC}_{\infty}$ & 0.040 \\
\hline & & rs2235033 & c. $1554+24 \mathrm{~T}>\mathrm{C}$ & 100 & 0.444 & $\mathrm{~T} / \mathrm{C}$ & $A \cup C_{\infty}$ & 0.028 \\
\hline & $A B C B / I$ & rs2287622 & c. 133 IT >C (p.Val444Ala) & 100 & 0.271 & $\mathrm{C} / \mathrm{T}$ & $\% \Delta \mathrm{LDL}-\mathrm{C}$ & 0.037 \\
\hline & $A B C B 4$ & rs2302387 & c. $175 \mathrm{C}>\mathrm{T}$ (p.Leu59=) & 100 & 0.220 & $\mathrm{C} / \mathrm{T}$ & $\mathrm{C}_{\max }$ & 0.029 \\
\hline & $A B C C I$ & rs 246221 & c.825T $>C(p . V a \mid 275=)$ & 100 & $0.44 I$ & $\mathrm{~T} / \mathrm{C}$ & $\% \Delta \mathrm{LDL}-\mathrm{C}$ & 0.005 \\
\hline & & rs4I48380 & c. $* 1293 \mathrm{G}>\mathrm{A}$ & 100 & 0.093 & $\mathrm{G} / \mathrm{A}$ & $\% \Delta \mathrm{LDL}-\mathrm{C}$ & 0.043 \\
\hline & $A B C C 2$ & rs2273697 & c. $1249 G>A$ (p.Val4|7|le) & 100 & 0.113 & G/A & $\% \Delta \mathrm{TC}$ & 0.003 \\
\hline & & & & & & & $\% \Delta \mathrm{LDL}-\mathrm{C}$ & 0.023 \\
\hline & $A B C G 2$ & rs 2231142 & c.42IC>A (p.Gln|4ILys) & 100 & 0.250 & $\mathrm{C} / \mathrm{A}$ & $\mathrm{CL}_{\mathrm{adj}}$ & 0.025 \\
\hline & SLC5A6 & rsI395 & c. I442C > T (p.Ser48IPhe) & 100 & 0.127 & $\mathrm{~T} / \mathrm{C}$ & $\% \Delta \mathrm{LDL}-\mathrm{C}$ & 0.029 \\
\hline & SLC7A7 & rs2281677 & c. $-86 \mathrm{~T}>\mathrm{C}$ & 100 & 0.364 & $\mathrm{C} / \mathrm{T}$ & $A \cup C_{\infty}$ & 0.029 \\
\hline & & & & & & & $\mathrm{C}_{\max }$ & 0.021 \\
\hline & SLC7A8 & rs7I4I505 & c. $-1065 G>T$ & 98.3 & 0.155 & $\mathrm{~T} / \mathrm{G}$ & $\mathrm{C}_{\max }$ & 0.034 \\
\hline & & rs2268877 & c. $152-1008 \mathrm{~T}>\mathrm{C}$ & 98.3 & 0.371 & $\mathrm{~T} / \mathrm{C}$ & $\mathrm{CL}_{\mathrm{adj}}$ & 0.038 \\
\hline & & rs910795 & c. $508+1988 \mathrm{~T}>\mathrm{C}$ & 98.3 & 0.293 & $\mathrm{~T} / \mathrm{C}$ & $\% \Delta$ LDL-C & 0.043 \\
\hline & SLCIOA2 & rs7987433 & c. $-457 A>G$ & 100 & 0.085 & $\mathrm{~A} / \mathrm{G}$ & $\% \Delta \mathrm{LDL}-\mathrm{C}$ & 0.045 \\
\hline & & rs 279942 & c. $* 373 C>G$ & 100 & 0.212 & $\mathrm{C} / \mathrm{G}$ & $\% \Delta \mathrm{TC}$ & 0.041 \\
\hline & SLC25A27 & rs938I468 & c. $299-1425 A>G$ & 100 & 0.483 & $\mathrm{G} / \mathrm{A}$ & $\% \Delta \mathrm{TC}$ & 0.043 \\
\hline & SLCOIA2 & rs7957203 & c.6I-5605T $>A$ & 100 & 0.271 & T/A & $\mathrm{AUC}_{\infty}$ & 0.039 \\
\hline & SLCOIBI & rs4l490I5 & c. $-910 G>A$ & 100 & 0.177 & $\mathrm{G} / \mathrm{A}$ & $\mathrm{C}_{\max }$ & 0.021 \\
\hline & & rs4l49056 & c.52IT>C (p.Vall 74Ala) & 100 & 0.177 & $\mathrm{~T} / \mathrm{C}$ & $\mathrm{C}_{\max }$ & 0.023 \\
\hline & SLCOIB3 & rs4l49II7 & c.334G > T (p.Ala I I 2Ser) & 98.4 & 0.320 & $\mathrm{G} / \mathrm{T}$ & $\mathrm{C}_{\max }$ & 0.010 \\
\hline & & rs73II358 & c.699G $>$ A (p.Met233lle) & 100 & 0.306 & $\mathrm{~A} / \mathrm{G}$ & $\mathrm{C}_{\max }$ & 0.010 \\
\hline & & rs2053098 & c. $1557 \mathrm{~A}>\mathrm{G}$ (p.Ala5|9=) & 100 & 0.314 & $\mathrm{G} / \mathrm{A}$ & $\mathrm{C}_{\max }$ & 0.010 \\
\hline & SLCO3AI & rs2283458 & c. $1513-1102 A>G$ & 100 & 0.398 & $\mathrm{G} / \mathrm{A}$ & $\mathrm{C}_{\max }$ & 0.025 \\
\hline & SLCO4AI & rs2236553 & c.797-286C $>\mathrm{T}$ & 100 & 0.195 & $\mathrm{~T} / \mathrm{C}$ & $A \cup C_{\infty}$ & 0.010 \\
\hline & & & & & & & $\mathrm{CL}_{\mathrm{adj}}$ & 0.017 \\
\hline & SLCO5AI & rs16936279 & c. $* 295 \mathrm{~A}>\mathrm{C}$ & 100 & 0.254 & $\mathrm{~A} / \mathrm{C}$ & $C_{\max }$ & 0.030 \\
\hline & & & & & & & $\mathrm{CL}_{\mathrm{adj}}$ & 0.043 \\
\hline \multirow[t]{8}{*}{ Others } & $A H R$ & rs2066853 & c. 166 IG $>$ A (p.Arg554Lys) & 100 & 0.415 & $\mathrm{G} / \mathrm{A}$ & $\% \Delta \mathrm{LDL}-\mathrm{C}$ & 0.028 \\
\hline & ATP7B & rs2277448 & c. $-75 \mathrm{C}>\mathrm{A}$ & 100 & 0.390 & $\mathrm{~A} / \mathrm{C}$ & $\mathrm{C}_{\max }$ & 0.031 \\
\hline & СОМT & rs4633 & c. $36 \mathrm{C}>\mathrm{T}(\mathrm{p} . \mathrm{His} \mid 2=)$ & 100 & 0.254 & $\mathrm{C} / \mathrm{T}$ & $\% \Delta \mathrm{TC}$ & 0.006 \\
\hline & & rs4680 & c.322G >A (p.Val I08Met) & 100 & 0.263 & $\mathrm{G} / \mathrm{A}$ & $\% \Delta \mathrm{TC}$ & 0.007 \\
\hline & $N R / 12$ & rs38I4055 & c. $-1135 \mathrm{C}>\mathrm{T}$ & 98.3 & 0.302 & $\mathrm{C} / \mathrm{T}$ & $A \cup C_{\infty}$ & 0.023 \\
\hline & & & & & & & $\mathrm{CL}_{\mathrm{adj}}$ & 0.022 \\
\hline & PGAP3 & rs2952I5I & c. $* 560 \mathrm{~T}>\mathrm{C}$ & 100 & 0.458 & $\mathrm{~T} / \mathrm{C}$ & AUC $C_{\infty}$ & 0.010 \\
\hline & & & & & & & $\mathrm{CL}_{\text {adj }}$ & 0.012 \\
\hline
\end{tabular}

Abbreviations: $\mathrm{AA}$, amino acid; $\mathrm{AUC} \mathrm{C}_{\infty}$, area under the plasma concentration curve from hour 0 to infinity; $\mathrm{CL}_{\text {adj }}$, clearance adjusted with body weight; $\mathrm{C}_{\max }$, maximum drug concentration in plasma; \% $\Delta \mathrm{LDL}-\mathrm{C}$, percentage change in low-density lipoprotein cholesterol from baseline to 48 hours after atorvastatin administration; MAF, minor allele frequency; $\% \Delta \mathrm{TC}$, percentage change in total cholesterol from baseline to 48 hours after atorvastatin administration. 
Table S2 Pharmacokinetic parameters and lipid-lowering response of SLCOIBI c.-9I0G $>$ A, SLCOIB3 c.334G $>$ T, and ABCC2 c. $1249 \mathrm{G}>\mathrm{A}$

\begin{tabular}{|c|c|c|c|c|c|c|}
\hline Variable & Unit & Genotype & & & FC (95\% Cl) & $P$-value \\
\hline SLCOIBI C.-9I0G $>$ A & & G/G & G/A & A/A & & \\
\hline $\mathrm{n}$ & & 33 & 14 & 3 & & \\
\hline \multirow[t]{2}{*}{$A \cup C_{\infty}$} & $\mathrm{ng} \cdot \mathrm{h} / \mathrm{mL}$ & $\mid 56 \pm 80.5^{a}(5 \mid .5 \%)$ & | 73 \pm 79.7 (46.0\%) & $333 \pm 181(54.4 \%)$ & $1.00(0.77-1.3 \mathrm{I})^{\mathrm{b}}$ & 0.077 \\
\hline & & $(48.9-403)$ & $(86.2-334)$ & $(147-509)$ & $1.89(0.39-9.10)^{\mathrm{c}}$ & \\
\hline \multirow[t]{2}{*}{$\mathrm{CL}_{\text {adj }}$} & $\mathrm{L} /(\mathrm{h} \cdot \mathrm{kg})$ & $9.54 \pm 4.90(51.4 \%)$ & $8.01 \pm 3.38(42.3 \%)$ & $5.1 I \pm 3.6 I(70.6 \%)$ & $0.77(0.59-1.00)$ & 0.099 \\
\hline & & $(2.48-25.2)$ & $(2.85-15.0)$ & $(2.46-9.22)$ & $0.46(0.08-2.46)$ & \\
\hline \multirow[t]{2}{*}{$\mathrm{C}_{\max }$} & $\mathrm{ng} / \mathrm{mL}$ & $33.5 \pm 16.7(49.7 \%)$ & $34.0 \pm 14.9(43.8 \%)$ & $76.5 \pm 26.4(34.4 \%)$ & $0.92(0.7|-| .2 \mid)$ & 0.021 \\
\hline & & $(9.50-81.6)$ & $(10.9-69.7)$ & $(46 . I-92.2)$ & $2.18(0.8 \mathrm{I}-5.84)$ & \\
\hline \multirow[t]{2}{*}{$\% \Delta \mathrm{TC}$} & $\%$ & $-10.0 \pm 11.6(-117 \%)$ & $-10.7 \pm 8.23(-76.9 \%)$ & $-10.1 \pm 7.36(-73.1 \%)$ & & 0.992 \\
\hline & & $(-3 \mid .9$ to || .8$)$ & $(-27.7$ to 4.00$)$ & $(-16.6$ to -2.10$)$ & & \\
\hline \multirow[t]{2}{*}{$\% \Delta T G$} & $\%$ & $\mid 4.4 \pm 74.3(5 \mid 8 \%)$ & $-16.6 \pm 34.5(-208 \%)$ & $1.70 \pm 16.8$ (986\%) & & 0.659 \\
\hline & & $(-68.1$ to 258$)$ & $(-62.5$ to 34.4$)$ & $(-10.6$ to 20.8$)$ & & \\
\hline \multirow[t]{2}{*}{$\% \Delta \mathrm{LDL}-\mathrm{C}$} & $\%$ & $-13.7 \pm 23.5(-172 \%)$ & $-17.6 \pm 14.5(-82.4 \%)$ & $-19.5 \pm \mid 4.8(-75.7 \%)$ & & 0.948 \\
\hline & & $(-58.2$ to 36.0$)$ & $(-45.6$ to 7.40$)$ & $(-29.1$ to -2.50$)$ & & \\
\hline SLCOIB3 C.334G $>T$ & & G/G & $\mathbf{G} / \mathbf{T}$ & $\mathbf{T} / \mathbf{T}$ & & \\
\hline$n$ & & 28 & 16 & 6 & & \\
\hline \multirow[t]{2}{*}{$A \cup C_{\infty}$} & $\mathrm{ng} \cdot \mathrm{h} / \mathrm{mL}$ & $|5| \pm 86.8(57.4 \%)$ & $172 \pm 68.9$ (40.1\%) & $267 \pm I 42(53.2 \%)$ & $1.06(0.86-1.30)^{\mathrm{b}}$ & 0.069 \\
\hline & & $(48.9-403)$ & $(97.6-334)$ & $(126509)$ & $1.57(0.91-2.72)^{c}$ & \\
\hline \multirow[t]{2}{*}{$\mathrm{CL}_{\text {adj }}$} & $\mathrm{L} /(\mathrm{h} \cdot \mathrm{kg})$ & $10.1 \pm 5.27(52.0 \%)$ & $7.72 \pm 2.55(33.0 \%)$ & $5.85 \pm 3.00$ (51.3\%) & $0.72(0.59-0.88)$ & 0.109 \\
\hline & & $(2.48-25.2)$ & $(2.85-11.9)$ & $(2.46-9.74)$ & $0.51(0.29-0.90)$ & \\
\hline \multirow[t]{2}{*}{$\mathrm{C}_{\max }$} & $\mathrm{ng} / \mathrm{mL}$ & $31.4 \pm 15.7(49.9 \%)$ & $34.7 \pm 15.5(44.6 \%)$ & $63.0 \pm 25.0(39.6 \%)$ & $1.01(0.80-1.28)$ & 0.010 \\
\hline & & $(9.50-65.4)$ & $(\mid 0.9-81.6)$ & $(36.6-92.2)$ & $1.88(1.21-2.87)$ & \\
\hline \multirow[t]{2}{*}{$\% \Delta \mathrm{TC}$} & $\%$ & $-8.27 \pm 12.1(-147 \%)$ & $-12.1 \pm 6.93(-57.1 \%)$ & $-13.9 \pm 8.90(-64.1 \%)$ & & 0.070 \\
\hline & & $(-31.2$ to 11.8$)$ & $(-31.9$ to 1.80$)$ & $(-27.7$ to -2.10$)$ & & \\
\hline \multirow[t]{2}{*}{$\% \Delta T G$} & $\%$ & $12.5 \pm 78.3(625 \%)$ & $-0.79 \pm 43.4(-5,470 \%)$ & $-15.3 \pm 28.5(-187 \%)$ & & 0.770 \\
\hline & & $(-68.1$ to 257.5$)$ & $(-62.5$ to 128$)$ & $(-57.7$ to 20.8$)$ & & \\
\hline \multirow[t]{2}{*}{$\% \Delta \mathrm{LDL}-\mathrm{C}$} & $\%$ & $-11.4 \pm 25.9(-227 \%)$ & $-16.9 \pm 6.05(-35.7 \%)$ & $-27.3 \pm 14.0(-51.2 \%)$ & & 0.201 \\
\hline & & $(-58.2$ to 36.0$)$ & $(-26.8$ to -3.40$)$ & $(-45.6$ to -2.50$)$ & & \\
\hline$A B C C 2$ c. $1249 G>A$ & & G/G & $\mathbf{G} / \mathbf{A}$ & & & \\
\hline $\mathrm{n}$ & & 43 & 7 & & & \\
\hline \multirow[t]{2}{*}{$A \cup C_{\infty}$} & $\mathrm{ng} \cdot \mathrm{h} / \mathrm{mL}$ & $172 \pm 92.1(53.6 \%)$ & $170 \pm 119$ (69.7\%) & & $0.80(0.42-1.53)^{\mathrm{b}}$ & 0.547 \\
\hline & & $(48.9-509)$ & $(58.2-342)$ & & & \\
\hline \multirow[t]{2}{*}{$\mathrm{CL}_{\mathrm{adj}}$} & $\mathrm{L} /(\mathrm{h} \cdot \mathrm{kg})$ & $8.69 \pm 4.30(49.5 \%)$ & $9.81 \pm 6.15(62.7 \%)$ & & $0.92(0.47-1.8 I)$ & 0.412 \\
\hline & & $(2.46-25.2)$ & $(2.7|-| 8.6)$ & & & \\
\hline \multirow[t]{2}{*}{$C_{\max }$} & $\mathrm{ng} / \mathrm{mL}$ & $35.7 \pm 17.9(50.3 \%)$ & $39.8 \pm 28.1$ (70.6\%) & & $0.88(0.43-1.81)$ & 0.642 \\
\hline & & $(9.70-92.2)$ & $(9.50-91.3)$ & & & \\
\hline \multirow[t]{2}{*}{$\% \Delta \mathrm{TC}$} & $\%$ & $-\mid 1.9 \pm 9.81(-82.7 \%)$ & $0.23 \pm 8.11(3,549 \%)$ & & & 0.003 \\
\hline & & $(-31.9$ to 9.80$)$ & $(-8.70$ to $I 1.8)$ & & & \\
\hline \multirow[t]{2}{*}{$\% \Delta \mathrm{TG}$} & $\%$ & I. $30 \pm 62.3(4,789 \%)$ & $27.2 \pm 77.0(283 \%)$ & & & 0.452 \\
\hline & & $(-68.1$ to 258$)$ & $(-62.5$ to 156$)$ & & & \\
\hline \multirow[t]{2}{*}{$\% \Delta \mathrm{LDL}-\mathrm{C}$} & $\%$ & $-17.4 \pm 20.3(-117 \%)$ & $-0.70 \pm 18.0(-2,565 \%)$ & & & 0.023 \\
\hline & & $(-58.2$ to 36.0$)$ & $(-26.6$ to 25.2$)$ & & & \\
\hline
\end{tabular}

Notes: a Mean \pm SD (CV) (range) of each variable according to genotype. bold change in heterozygotes compared to major homozygotes. ${ }^{\mathrm{b}}$ Fold change in minor homozygotes compared to major homozygotes.

Abbreviations: $\mathrm{AUC}_{\infty}$, area under the plasma concentration curve from hour 0 to infinity; $\mathrm{Cl}$, confidence interval; $\mathrm{CL}_{\text {adj }}$, clearance adjusted with body weight; $\mathrm{C}_{\max }$, maximum drug concentration in plasma; CV, coefficient of variation; FC, fold change; $\% \Delta L D L-C$, percentage change in low-density lipoprotein cholesterol from baseline to 48 hours after atorvastatin administration; SD, standard deviation; \% $\Delta \mathrm{TC}$, percentage change in total cholesterol from baseline to 48 hours after atorvastatin administration; \% $\Delta \mathrm{TG}$, percentage change in triglycerides from baseline to 48 hours after atorvastatin administration.

\section{Publish your work in this journal}

Drug Design, Development and Therapy is an international, peerreviewed open-access journal that spans the spectrum of drug design and development through to clinical applications. Clinical outcomes, patient safety, and programs for the development and effective, safe, and sustained use of medicines are the features of the journal, which has also been accepted for indexing on PubMed Central. The manuscript management system is completely online and includes a very quick and fair peer-review system, which is all easy to use. Visit http://www.dovepress.com/testimonials.php to read real quotes from published authors. 